\title{
森林表土を用いて吹付緑化した林道切土法面における 植生の動態について
}

\section{下園寿秋 ${ }^{1)} \cdot$ 前迫俊一 ${ }^{2)} \cdot$ 上野敏夫 ${ }^{3)} \cdot$ 中屋雅喜 ${ }^{4)}$}

1）鹿児島県林業試験場

2) 鹿児島県林業振興課

3）鹿児島県環境保護課

4）鹿児島県森林保全課

shimozono@kpfes.ecnet.jp

摘要 : 林道の切土法面に, 森林表土を利用した吹付緑化試験 を行った。3 区分の森林からそれぞれ表土を採取して発芽試 験を行い, 吹付施工のための表土を採取する森林を決定した。 施工後植生の変化を調査した結果, 表土吹付法面に出現する 種は発芽試験結果を反映せず, 対照区と比較して被覆率は劣 った。また, 帰化草本は早期に出現したが, 在来草本及び木 本類の出現は 1 年以上かかった。 キーワード : 森林表土, 林道, 切土法面, 帰化種, 在来種

\section{1. はじめに}

鹿児島県における林道の切土法面では, 外来の牧草種子主 体の吹き付けにより緑化を行っている。しかしながら，導入 した外来植物は，地域に自生する植物を駆逐する等様々な問 題が指摘されており ${ }^{3)}$, 現場サイドからは, 緑化された法面 は植物が高密度で被覆しているため, 周辺の自生植物が侵入 するのに時間がかかるとの声もある。この対策として，世界

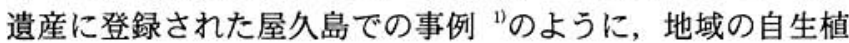
物種子を活用することも考えられるが，この種子採取は外来

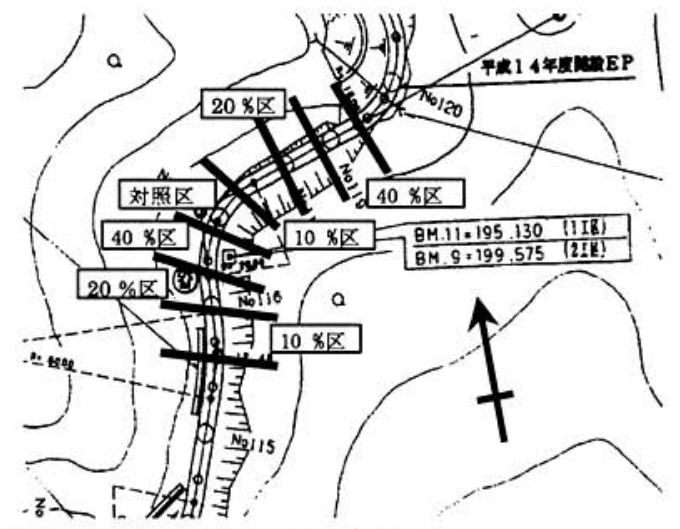

图-1 林道鳴石線における試験区の位置
種子の購入より経費がかかり, 県本土民有林のように環境保 全的法律規制にあまり左右されない森林に開設される林道で は採用されにくいのが現状である。このようなことから全国 的に事例があり, 法面に自生植物を容易に定着させることが できる工法である，森林表土を利用した吹付試験を行った。

\section{2. 調查地及ひ試硂方法の根要}

\section{1 試験地の概要}

試験は, 本県の薩摩半島南西部に位置する加世田市の県営 林道鳴石線において, 平成 14 年度施工区間（延長 $160 \mathrm{~m}$ ） の切土法面で行った。法面は標高 $220 \mathrm{~m}$ 付近, 基岩は砂岩, 方位は $\mathrm{N} 8^{\circ} \mathrm{W}$ から $\mathrm{S} 86^{\circ} \mathrm{W}$ の北北西から南南西向き, 法面勾 配は 1:0.8 (51.2 $\left.2^{\circ}\right)$, 法長は $8 \mathrm{~m}$ から $14 \mathrm{~m}$ である。

2.2 植生調查及び表土発芽試験

当該区間はマテバシイが優占する天然林, ヒノキ人工林, ツブラジイが優占する天然林の 3 区分の森林を通過するた め, 2002 年 4 月に $10 \mathrm{~m}$ 四方の方形区を 1 箇所づつ設置し て，階層区分を行い，Braun-Blanquet の優占度 ${ }^{5}$ を調べた。 その後各方形区の中央付近に $50 \mathrm{~cm}$ 四方の枠を設け, その 中の落葉層を除く地表から深さ $10 \mathrm{~cm}$ までの表土を採取し, 試験場に持ち帰り発芽試験を行った。表土は $7 \mathrm{~mm}$ の穊い で石や落葉等を除去し, 育苗箱（34 cm×49 cm×9 cm）に鹿

表-1 試験区別種子吹付量と希望生育本数

\begin{tabular}{|c|c|c|c|c|c|c|c|c|}
\hline \multirow[b]{3}{*}{ 次 if } & \multicolumn{2}{|c|}{ 㭠 } & \multicolumn{2}{|r|}{$n$} & \multicolumn{2}{|c|}{ 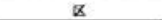 } & \multicolumn{2}{|l|}{ 名 } \\
\hline & \multicolumn{2}{|c|}{ 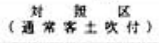 } & \multicolumn{2}{|c|}{$10 \mathrm{~N} \times x$} & \multicolumn{2}{|c|}{$20 \mathrm{~N} / x$} & \multicolumn{2}{|c|}{$40 \leqslant x$} \\
\hline & $\begin{array}{l}\text { 放 it a } \\
\left.\text { (kd } 100 \mathrm{~m}^{3}\right)\end{array}$ & 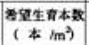 & $\begin{array}{l}\text { of } \text { 付 } \\
\text { Oxef } 100 \mathrm{~m}^{2}\end{array}$ & 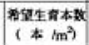 & $\begin{array}{l}\text { 放 付 } \\
\left.\text { (kgr } 100 \mathrm{~m}^{2}\right)\end{array}$ & 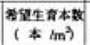 & 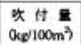 & 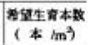 \\
\hline トールフエスク & 0.294 & 600 & 0.400 & 820 & 0.400 & 820 & 0.400 & 820 \\
\hline ウィーヒンタクラフタラス & 0.042 & 600 & & & & & & \\
\hline ホワイトクローター & 0.050 & 400 & & & & & & \\
\hline ヨモキ & 0.073 & 1.000 & & & & & & \\
\hline 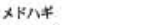 & 0.325 & 1.000 & & & & & & \\
\hline ヤマハキ & 0.610 & 400 & & & & & & \\
\hline It & 1.434 & 4.000 & 0.400 & 820 & 0.400 & 800 & 0.400 & 800 \\
\hline
\end{tabular}


表-2 植生調査結果

\begin{tabular}{|c|c|c|c|c|c|c|c|c|c|c|c|c|c|c|}
\hline \multicolumn{5}{|c|}{ Plot.1 } & \multicolumn{5}{|c|}{ Plot.2 } & \multicolumn{5}{|c|}{ Plot 3} \\
\hline 方售 & \multicolumn{4}{|c|}{$\mathrm{N} 50^{\circ} \mathrm{W}$} & 有位 & \multicolumn{3}{|c|}{$\mathrm{N} 7 \mathrm{~N}^{\circ} \mathrm{W}$} & & 方位 & \multicolumn{4}{|c|}{$\mathrm{N} 65^{\circ} \mathrm{W}$} \\
\hline 颀科 & \multicolumn{4}{|c|}{$33^{\circ}$} & 道积 & \multicolumn{3}{|c|}{$40^{\circ}$} & & 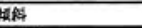 & \multicolumn{4}{|c|}{$40^{\circ}$} \\
\hline 触面形 & \multicolumn{4}{|c|}{ 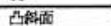 } & 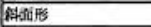 & \multicolumn{3}{|c|}{ 平家新面 } & & 的面形 & \multirow{2}{*}{\multicolumn{4}{|c|}{ 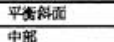 }} \\
\hline 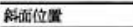 & \multicolumn{4}{|c|}{ 中殒 } & 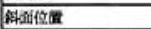 & \multicolumn{3}{|c|}{ 中国 } & & 倁面位贯 & & & & \\
\hline 名 & 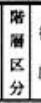 & & 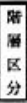 & $\begin{array}{l}\text { 散 } \\
\text { 政 }\end{array}$ & 名 & 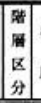 & \begin{tabular}{|l|l|} 
& \\
\\
\end{tabular} & 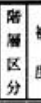 & 娄 & 释名 & 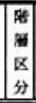 & 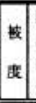 & 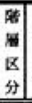 & 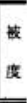 \\
\hline ッフララン & BI & 4 & & & 七ノキ & BI & 4 & & & マテバシイ & $\mathrm{B1}$ & 4 & & \\
\hline スタ夕:1 & BI & 1 & & & 峄 & $\mathrm{B1}$ & + & & & コハンモチ & $\mathrm{B1}$ & + & $\mathrm{B} 2$ & + \\
\hline サカキ & 82 & 1 & & & タフォキ & $\mathrm{B} 2$ & + & & & スタジィ & $\mathrm{Bl}$ & + & $s$ & + \\
\hline アラカシ & 82 & + & $\mathrm{s}$ & + & アオキ & $\mathrm{s}$ & + & & & ハぜノキ & B1 & + & & \\
\hline イスノキ & $\mathrm{B} 2$ & + & & & アラカシ & $\mathrm{s}$ & + & & & ヤマザクラ & B1 & + & & \\
\hline ウラシロササシ & $\mathrm{P} 2$ & + & & & イスセンリョウ & $\mathrm{s}$ & + & & & クチナシ & $\mathrm{B} 2$ & . & $\mathrm{s}$ & + \\
\hline クロガネモチ & $\mathrm{B} 2$ & + & & & イヌビワ & $\mathbf{s}$ & + & & & シロタモ & 82 & + & & \\
\hline クロキ & $\mathrm{B} 2$ & + & $\mathrm{s}$ & + & エコノキ & $\mathrm{s}$ & + & & & タプキ & $\mathrm{B} 2$ & + & & \\
\hline コバンモチ & $\mathrm{B} 2$ & + & & & コカカクウッキ & $\mathrm{s}$ & + & & & ネスミモチ & $B 2$ & . & & \\
\hline タイミンタチバナ & 82 & + & $\mathrm{s}$ & + & コナラ & $\mathrm{s}$ & + & & & ハクサンボク & $\mathrm{B} 2$ & + & & \\
\hline タフルキ & $\mathrm{B} 2$ & + & s & + & בバンモチ & $\mathrm{s}$ & + & & & ヒサカキ & $\mathrm{B} 2$ & 2 & & \\
\hline ネスミモチ & $\mathrm{B} 2$ & + & . & & シャシャャン杂 & $\mathrm{s}$ & + & & & モチノキ & $\mathrm{B} 2$ & . & & \\
\hline ハクサンボク & 82 & + & $\mathrm{s}$ & + & シ口多 & $\mathrm{s}$ & + & & & ヤブッバキ & $\mathrm{B} 2$ & + & & \\
\hline ハせノキ & 82 & + & & & タイミンタチバす & $\mathrm{s}$ & + & & & アラカシ & $s$ & + & & \\
\hline ホルトノキ & $\mathrm{B} 2$ & + & & & ソフラジィ & $\mathrm{s}$ & + & & & イスセンリョウ & $\mathrm{s}$ & + & & \\
\hline ヤマピワ & 82 & 1 & & & ソルタミ & $\mathrm{s}$ & + & & & イヌビワ & $\mathrm{s}$ & + & & \\
\hline ギョクシンカ & $\mathrm{s}$ & + & & & ネスミモチ & $\mathrm{s}$ & + & & & ウラジロカサシ & $\mathrm{s}$ & + & & \\
\hline ナッフシ & $\mathrm{s}$ & + & & & ハクサン゙゙ク & $\mathrm{s}$ & + & & & エコノキ & $\mathrm{s}$ & + & & \\
\hline ヒサカキ & $\mathrm{s}$ & + & & & ハドノキ & $\mathrm{s}$ & + & & & クサギ & $\mathrm{s}$ & + & & \\
\hline モチノキ & $\mathrm{s}$ & + & & & ハナイカタ & $\mathrm{s}$ & + & & & ソルウメモドキ & $s$ & + & & \\
\hline ヤプハイキ & $s$ & + & & & ヒサカキ & $\mathrm{s}$ & + & & & ナナメノキ & $\mathrm{s}$ & + & & \\
\hline アオツツラフシ・ & $\mathrm{H}$ & + & & & マルバウツキ & $\mathrm{s}$ & + & & & ヤマビワ & $\mathrm{s}$ & + & & \\
\hline ウラシロッ & $\mathrm{H}$ & + & & & ヤプッパキ & $\mathrm{s}$ & + & & & ウマノススクザ & $\mathrm{H}$ & + & & \\
\hline オオカダマッ & $\mathrm{H}$ & + & & & ウラジロル & $\mathrm{H}$ & 2 & & & ギンリョウソウ & $\mathrm{H}$ & + & & \\
\hline サルトリイバラ & $\mathrm{H}$ & + & & & アオツツラフジ・ & $\mathrm{H}$ & + & & & コバノカナワラビッ & $\mathrm{H}$ & + & & \\
\hline ッワプキャ & $\mathrm{H}$ & + & & & アマクサシタッ & $\mathrm{H}$ & + & & & ックプキャ & $\mathrm{H}$ & + & & \\
\hline トキワカモメツル* & $\mathrm{H}$ & + & & & ウマノススクザ & $\mathrm{H}$ & + & & & 八ナミョウガ & $\mathrm{H}$ & - & & \\
\hline ハナミョウガ & $\mathrm{H}$ & + & & & カヤツリダサ科s" & $\mathrm{H}$ & + & & & & & & & \\
\hline & & & & & コシタッ & $\mathrm{H}$ & + & & & & & & & \\
\hline & & & & & コハノカナワラビッ & $\mathrm{H}$ & + & & & & & & & \\
\hline & & & & & サネカズラ & H & + & & & & & & & \\
\hline & & & & & タッナミソヴ & $\mathrm{H}$ & + & & & & & & & \\
\hline & & & & & チチミザザ & $\begin{array}{l}\mathrm{H} \\
\mathrm{H}\end{array}$ & $i_{+}^{+}$ & & & & & & & \\
\hline & & & & & ホウロクイチコ & & + & & & & & & & \\
\hline & & & & & ホラシノブル & $\mathrm{H}$ & + & & & & & & & \\
\hline & & & & & ミソシタ" & $\mathrm{H}$ & + & & & & & & & \\
\hline & & & & & ムサシアフミ゙ & $\mathrm{H}$ & + & & & & & & & \\
\hline & & & & & ヤマイモル & $\mathrm{H}$ & + & & & & & & & \\
\hline 合鼓 28 和 & & & & & 合新 40 每 & & & & & 合郤 27 程 & & & & \\
\hline
\end{tabular}

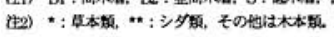

沼土とさし芽土の $1: 1$ の混合土を $4 \mathrm{~cm}$ 厚で入れ, その上に 表土を $2 \mathrm{~cm}$ 厚で敷き, 場内のハウスに置いた。試験は 2 回 繰り返した。周辺からの侵入種を把握するため, 混合土だけ の育苗箱も 1 箱置いた。かん水は自動で 8 時 30 分, 11 時, 14 時, 17 時の 1 日 4 回, 60 秒間行った。同年 10 月までの出 現種数と本数から, 吹き付けに使用する表土を採取する森林 を決定した。

\section{3 切土法面への表土吹付試験}

当該切土法面の吹き付けは現地調査及び本県の「林道切土 法面における吹付工の選定フロー」により客土吹付工を選定 した。これはピートモス, パーク堆肥等から成る基盤材 $\left(2,600 \mathrm{~L} / 100 \mathrm{~m}^{2}\right)$ と化成肥料, 接合剂, トールフェスク, ウィーピングラブグラス, ホワイトクローバー, ヨモギ, メ ドハギ, ヤマハギの 6 種の種子を混ぜて吹き付ける工法で, 吹付厚は約 $2 \mathrm{~cm}$ である。本試験では, 表土の混合割合を基 盤材に対して $10 \%, 20 \%, 40 \%$ とした。対照は通常の客 土吹付とし, 対照区を挟むように 2 回反復の表土吹付試験 区（以下，表土区という。）を設置した（図-1）。雨水による 法面の土砂流出等を防止するため, 表土区も初期緑化を行
表-3 表土の発芽試験結果（単位：本）

\begin{tabular}{|c|c|c|c|}
\hline 種 & Plot.1 & Plot.2 & Plot. 3 \\
\hline \multicolumn{4}{|l|}{ 䂞本類 } \\
\hline アカメガシワ & & & 1 \\
\hline イズセンリョウ $(2,3)$ & 9 & 2 & 3 \\
\hline イタビカズラ & 1 & & \\
\hline イヌビワ $(2,3)$ & 1 & & 1 \\
\hline カラスザンショウ & & & 1 \\
\hline キブシ & 3 & 8 & 11 \\
\hline クサギ & 1 & & \\
\hline クマイチゴ & 5 & 1 & 5 \\
\hline コウソ & & & 1 \\
\hline コバンノキ & 1 & & 2 \\
\hline サルナシ & 4 & 1 & 7 \\
\hline タラノキ & & 1 & 1 \\
\hline ナガバモミジイチゴ & & & 5 \\
\hline ハゼノキ $(1,3)$ & 3 & 5 & 7 \\
\hline ハドノキ $(2)$ & & 2 & \\
\hline ヒサカキ $(1,2,3)$ & 43 & 5 & 17 \\
\hline ヒノキ(2) & & 2 & \\
\hline ヒメバライチゴ & 3 & & 9 \\
\hline ホルトノキ & 1 & & \\
\hline ムラサキシキブ & 1 & 1 & 1 \\
\hline \multicolumn{4}{|l|}{ 草本類 } \\
\hline \multicolumn{4}{|l|}{ 㷌化種 } \\
\hline イヌホオズキ & 1 & 1 & 2 \\
\hline オオアレチノギク & 1 & & \\
\hline セイタカアワダチソウ & 2 & 1 & 2 \\
\hline チチコグサモドキ & & 1 & 3 \\
\hline \multicolumn{4}{|l|}{ 在来種 } \\
\hline オトコエシ & & 2 & \\
\hline キランソウ & & 7 & \\
\hline コアカソ & 1 & 9 & 5 \\
\hline コナスビ & & 3 & 1 \\
\hline タケニグサ & & 3 & 1 \\
\hline タチツポスミレ & & 2 & 9 \\
\hline ツボクサ & & 1 & 22 \\
\hline ノブドウ & & & 1 \\
\hline メヒシバ & 2 & 1 & \\
\hline \multicolumn{4}{|l|}{ 種不明 } \\
\hline イネ科 $\mathrm{sp}$ & 6 & 1 & \\
\hline カヤツリグサ科 sp & & 5 & 4 \\
\hline キク科 sp & 3 & 23 & 2 \\
\hline 計 & 92 & 88 & 124 \\
\hline
\end{tabular}

注1) 本数は, 2 回反復の平均値である。

注2）㛿化種の判別は, 清水編 ${ }^{4}$ によったが, 史前帰化 植物 ${ }^{4}$ は「在来種」とした。

注3）種名に記載してある括弧書きの数字はプロット番

号であり, 当該番号の方形区内に出現し, かつ表土 発芽試験でも発芽した種であることを表す。

った。吹き付ける種はトールフェスクとし, 自生種を容易に 侵入させるため, 種子量を 6 種合計の約 3 割に削減した（表 -1)。表土は工事発注後の 2002 年 10 月に採取した。小型バ ックホウで表土を大型土のうに詰め, 現場内に保管した。吹 き付けは同年 12 月に施工した。保管した表土を笁い機に 2 回かけて石や落葉等を除き, 細かい粒状にして基盤材やトー ルフエスク種子等と混合し吹き付けた。施工後, $1 \mathrm{~m}$ 四方 の方形区を 1 箇所づつ設置し, 対照区には 2 箇所設置した。 
表-4 経過年月ごとの試験区別出現種とその数

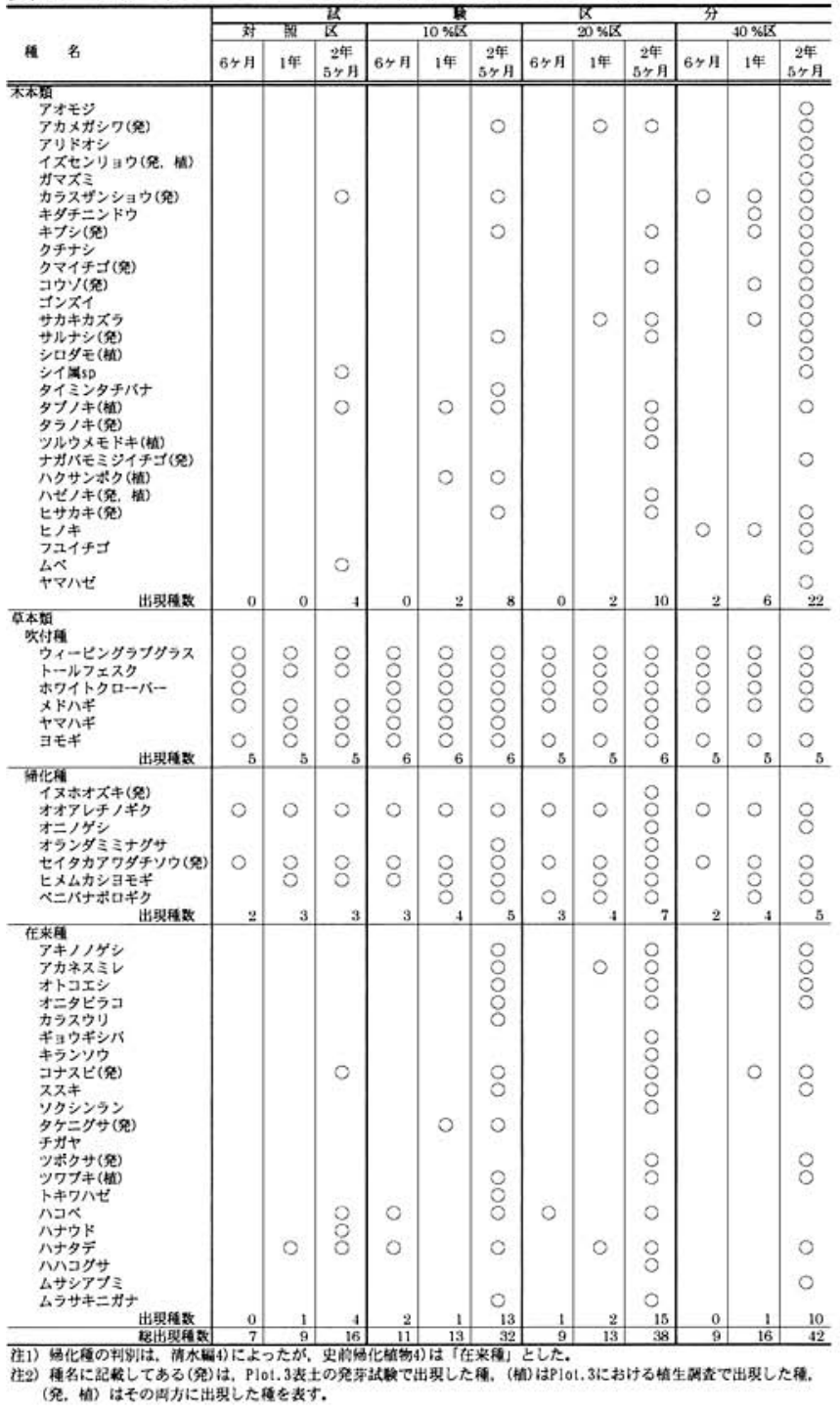

植生経過調查は 2003 年 4 月から $1 \sim 2$ ケ月おきに行っ た。方形区内は出現種別の本（株）数, 被覆率を調べ, 方形 区外の法面に出現する植物種も試験区別に調べた。

\section{3. 桔果}

\section{1 表土採取地付近の植生と発芽試験}

植生調查の結果を表·2 に示す。Plot.1 はツブラジイ優占 の林に設置した。樹高 $13 \mathrm{~m}$ のツブラジイ, スダジイが高木 層, 亜高木層にはイスノキ, タブノキ等のほかに陽樹である ハゼノキもあり, 全体で 28 種出現していた。Plot.2 はヒノ キ人工林内に設置した。樹高 $12 \mathrm{~m}$ のヒノキの下層には, 木 本・草本・シタ類併せて 40 種出現しており, 最も出現種数 が多かった。Plot.3 はマテバシイ優占の林に設置した。樹高 $12 \mathrm{~m}$ の高木層には八ゼノキ, ヤマザクラなど陽地に生える 樹種もあり, 下層にはタブノキ, アラカシ等が生え, 全体で
27 種出現していた。

発芽試験結果を表·3 に示す。周辺からの侵入種はカタバ ミとタネッケバナであったので, その本数は除外した。発芽 種数は 36 種で, うち 20 種は木本類, 16 種は草本類であっ た。植生調査で出現した種は 6 種があり, すべて木本類で あった。草本類のうち 4 種は帰化種であった。木本, 草本 類ともに陽生の種が多く, 表土の発芽結果は, 採取した箇所 付近の植生をあまり反映しなかった。発芽本数は, Plot.3 表 土からの発芽が出現種, 本数ともに最も多かった。吹き付け る表土は, マテバシイ優占の林から採取することに決めた。 3.2 法面に出現した試験区ごとの種組成

施工から 6 ケ月 (2003 年 6 月), 1 年 (同年 12 月), 2 年 5 ケ月（2005 年 5 月）後の法面に出現した種とその数を表・4 に示す。各区とも経過年月に伴い種数が増加した。木本類は 発芽試験で確認された 20 種のうち 11 種が出現したが, 全 表土区に出現している種もあれば, そうでない種もあった。 タブノキ, ヒノキ等は法面直上の樹木からの散布と推察され た。全体的には 1 年経過後から種数が増加し, 特に $40 \%$ 区 は種数が最も多かった。対照区も 2 年 5 ケ月から木本類が 現れ，ムべは鳥類による散布と思われた。表土区での草本類 は, トールフェスクを除く吹付種も出現した。これは 2003 年 4 月から確認されており, 対照区からの種子の飛来や既 設法面からの侵入と考えられた。草本類の帰化種は 7 種が 侵入していた。特にオオアレチノギク, セイタカアワダチソ ウは早くから全区に侵入していた。草本類の在来種は脪化種 ほど早くなく, そのほとんどが 1 年後から侵入していた。 発芽試験で確認された種は 3 種出現していたが, タケニグ サは 10 \%区でしか出現しなかった。草本の在来種は他に 18 種が侵入しており, 対照区より表土区の方が種数が多かった。 3.3 方形区内の被覆率の経年変化

方形区内の植物の被覆率の経年変化を図· 2 に示す。施工 後 4 ヶ月 (2003 年 4 月), 6 ヶ月 (同年 6 月), 1 年 (同年 12 月), 1 年 7 ケ月 (2004 年 7 月), 2 年 (2004 年 12 月), 2 年 5 ケ月 (2005 年 5 月) ごとに 2 回反復の平均値を示した。 出現種を吹付種, 侵入吹付種, 帰化草本 (草本類のうち帰化 種), 在来草本 (草本類のうち在来種), 木本類の 5 つに区 分した。吹付種とは今回吹き付けた種であり, 対照区では 6 種, 表土区ではトールフェスクのみを指す。侵入吹付種は表 土区において区別した。前述のトールフェスクを除く 5 種 を指す。表土区でもこの 5 種が出現したためである。被覆 率は対照区が最も高く, 40 \%区が最低であった。2 年後か ら吹付種の被覆率が著しく低下したが 2 年 5 ヶ月ではやや 回復した。帰化草本, 在来草本, 木本類は, 年々被覆率が增 加していた。対照区の吹付種は 6 ケ月経過で 100 \%となっ たが経年的に減少し, その後 2 年 5 ヶ月で再び上昇した。 また, 対照区でも帰化草本は時間経過とともに增加した。10 $\%$ 区では 4 ヶ月で最大となり, その後減少した。吹付種のト 一ルフェスクは経年的に減少したが, 侵入吹付種は 1 年 7 . 


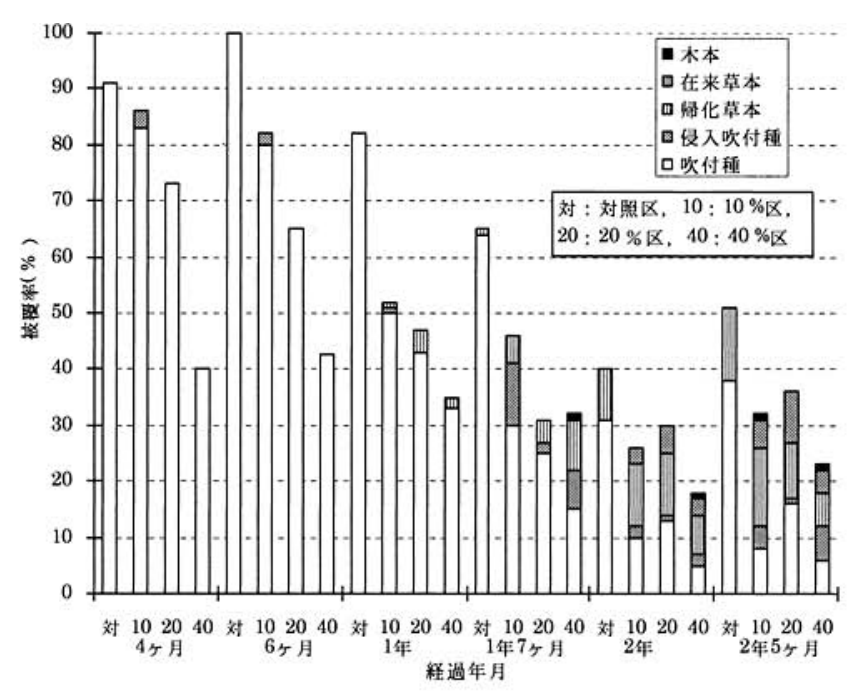

图-2 経過年月ごとの試験区別被覆率

ケ月経過から増減が激しくなった。これはホワイトクローバ 一, ヨモギの春から夏にかけての増加, 冬期の減少によるも ので, $20 \%$ 区, 40 \%区でもみられた。帰化草本, 在来草本, 木本類の被覆率は年々増加していた。20\%区，40\%区の経 年変化は全体的には $10 \%$ 区の変化と同様であったが, $40 \%$ 区は試験区の中で最低の被覆率を全期間示していた。

\section{4 方形区内の成立本数の経年変化}

方形区内に出現した植物の成立本数についての経年変化を 図-3 に示す。図示の詳細は図-2 と同じであり, 2 回反復の 平均值である。被覆率と同様, 全体本数は経年的に減少した。 吹付種の減少の他に帰化草本の増減も激しく, 当年生実生の 多数の発生と枯れによるものであった。在来草本, 木本類は 徐々に増加した。対照区の 4 ケ月での本数は全区の中で最 低であり, 希望生育本数（表-1）の 1/10 程度であった。そ の後時間経過とともに本数は減少した。 2 年 5 ヶ月では 4 ケ 月経過時の約 $1 / 4$ になり, 表土区とあまり変わらなくなった。 $10 \%, 20 \%$ 区の吹付種は 4 ケ月では最も高く, 希望成立本 数に最も近かった。その後経年的に減少し, 2 年 5 ヶ月では 4 ヶ月の約 $1 / 6$ まで減った。 $40 \%$ 区は当初の成立本数は低か ったが, 経年変化は他の表土区と同様であった。

\section{4. 考察}

今回の試験で, 法面の種組成は発芽試験結果がそのまま反 映されなかった。これは細木ら ${ }^{2}$ が指摘しているように，切 土法面特有の劣悪な立地条件が主な原因と考えられる。発芽 試験では適度な水分を保っているが, 法面は開放地であり, 急勾配に施工され, $2 \mathrm{~cm}$ 以下の吹付厚であること等から, 乾燥状態になりやすいため, 表土に内在する種子があまり発 芽しなかったものと推察される。

吹付種の被覆率や成立本数は, 各区とも経年的に減少して

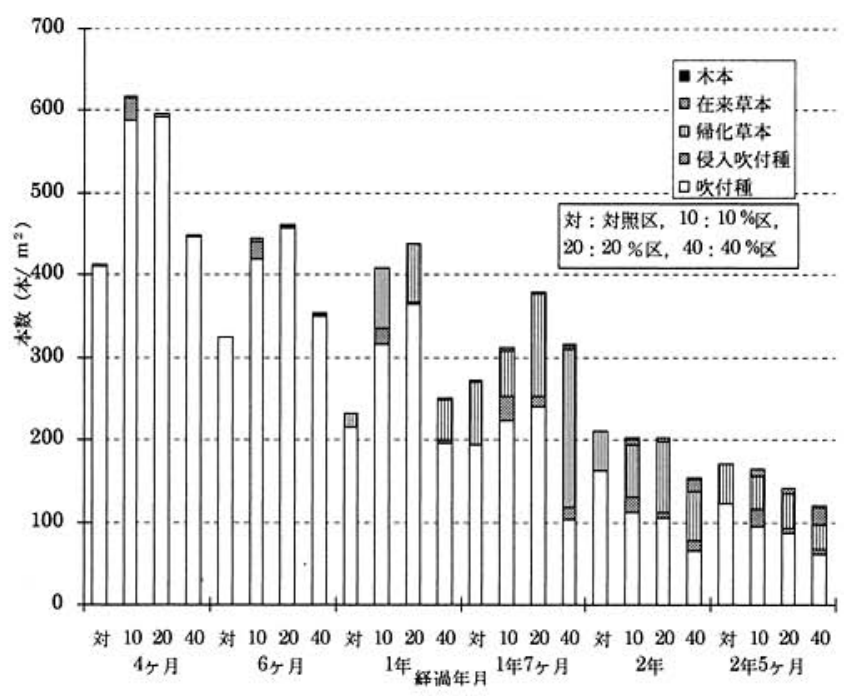

图-3 経過年月ごとの試験区別成立本数

いた。これは成長に伴う競争や乾燥による影響と考えられた が, 2 年 5 ケ月経過すると, 被覆率がやや増加しているので, 今後の経過を見守る必要がある。

配合率を変えて表土を吹き付けたが自生種, 特に在来草本 や木本類が出現するには, どの区でも 1 年以上かかる結果 となり, 帰化草本と比べて非常に緩慢であった。切土法面に おいて吹付種子並みの早期緑化を森林表土に求めることは困 難と考えられた。今回表土区においてトールフェスクにより, 種子量を削減して早期緑化を図ったように, 吹付種子による 最小限の早期緑化は, 法面保全と表土活用の両立のためにも 必要と考えられる。現在のところ, 試験地では法面流出等の 災害はない。表土の配合率については, これまでの結果から $40 \%$ 未満の配合率がよいと思われたが, 今後の植生変化や 他施工地での結果を踏まえ十分検討する必要がある。

\section{引用文献}

1）秋田賢人・下新原博也・牛島和昭（2001）屋久島における 自生種による樹林化の施工事例－播種工で導入した自生種の 生育推移と今後の課題一, 日本緑化工学会誌, 27(1): $250 \cdot 253$.

2）細木大輔・ 中村勝衛 - 亀山章（2005）切土のり面緑化にお ける植生基材吹付工を応用した森林表土の利用, 日本緑化工 学会誌, $30(3): 561-571$.

3）日本緑化工学会（2002）生物多様性のための緑化植物の取 り扱い方に関する提言, 日本緑化工学会誌, 27(3) : 481-491.

4）清水建美編（2003）日本の帰化植物, 平凡社, pp11-310.

5）森林立地調査法編集委員会編(1999) 森林立地調查法, 博友 社, $\mathrm{pp} 43 \cdot 46$.

(2005.6.25 受理) 